\title{
INVASIVE DUCTAL BREAST CANCER METASTASIS INTO THE TEMPOROMANDIBULAR JOINT TWO YEARS AFTER THE INITIAL TREATMENT: A CASE REPORT
}

\author{
Predrag Radović1,2, Milovan Papović1, Miloš Trajković1 ${ }^{1}$ Nikola Živković2,3, Andrija Ćosić1,2
}

\begin{abstract}
A tumor metastatic to the oral cavity and jaws is a relatively rare finding. These types of tumor represent a serious challenge for surgical oncologists, because of difficult diagnosis, unspecific symptomatology and atypical radiographic findings. The symptoms that occur with tumors metastatic to the temporomandibular joint and ramus of the lower jaw are usually unspecific, and usually include painful sensations, tumescence, difficulty opening mouth, which often mislead the clinician towards a temporomandibular joint disease, such as arthritis, joint subluxation, degenerative changes and infection.

In this case, the patient described is a 62-year-old woman, with a metastatic tumor in the temporomandi-bular joint and lower jaw region, and a very uncertain prognosis. In this paper, we will discuss surgical and oncological therapeutic options recommendable in this case, based on radiographic findings and histopathological cancer type.
\end{abstract}

Acta Medica Medianae 2020;59(1):90-95.

Key words: breast cancer metastasis, temporomandibular joint, histopathological type and subtype, surgical treatment

${ }^{1}$ Clinic of Dentistry, Department of Maxillofacial Surgery, Niš, Serbia

${ }^{2}$ University of Niš, Faculty of Medicine, Niš, Serbia

${ }^{3}$ Centar for Pathology and Pathological Anatomy, Clinical Center Niš, Niš, Serbia

Contact: Milovan Papović

48 Dr. Zoran Djindjić Blvd., 18000 Niš, Serbia

E-mail: milovanpapovic@gmail.com

\section{Introduction}

Metastatic tumors represent a rare pathological entity in the head and neck region, constituting about $1 \%$ of the total number of all malignant tumors affecting the region (HNR) (1).

Lymphatic and hematogenous dissemination of infraclavicular malignancies which metastasize to the HNR much more frequently occurs via the ductus thoracicus, compared to the spread via the Batson paraspinal venous plexus (2).

In the available literature, the occurrence of mtastatic tumors is described in all of the anatomical sections of the NHR, i.e. in the lymph nodes, salivary glands, and thyroid, while most of the studies reported so far have presented the data about the oral cavity and jaw soft tissue involvement (3).

The most frequent site of the primary tumor metastasizing to the NHR are lungs in men and breasts in women (4).

Clinical manifestations of the tumors metastatic to the region are rather diverse. These vary from the changes such as anamnestically longterm painless tumor formations involving the salivary gland, bulbous protrusions caused by retrobulbar processes, severe headaches, neck lymphadenopathy in the area covering the tumescences and pain in the region of jaws, exophytic and ulcerous changes in the oral cavity, followed by paresthesias and progressive tooth loss.

The occurrence of metastases in distant organs indicates the onset of the terminal disease stage, with the average patient survival from 3.7 to 32 months after the histopathological verification of metastatic disease (5).

We will here present the case of a patient with completed diagnostic and therapeutic procedures conducted in order to treat breast cancer metastasis to the lower jaw region.

\section{Case report}

A female patient aged 62 years was referred to the Clinic of Dentistry, Department for Maxillofacial Surgery in Niš by her oncologist, in order to have 
the tumefaction in the preauricular region on the right side treated (Figure 1).

Examining the medical documentation, we found the information about a surgical intervention on her right breast performed two years ago, which consisted of axillary dissection with radical mastectomy, along with adequate oncological therapy in order to treat the invasive ductal carcinoma.

Anamnestically, the patient had noticed the mentioned tumefaction in the right preauricular region three months before the presentation. The appearance and spontaneous enlargement of the tumefaction did not result in any subjective complaints. The sudden enlargement of the lesion, followed by reduced mouth opening and spontaneous episodes of bleeding from the tumor were the reasons for visiting her oncologist who, after the examination, referred the patient to the Maxillofacial Surgery Clinic.

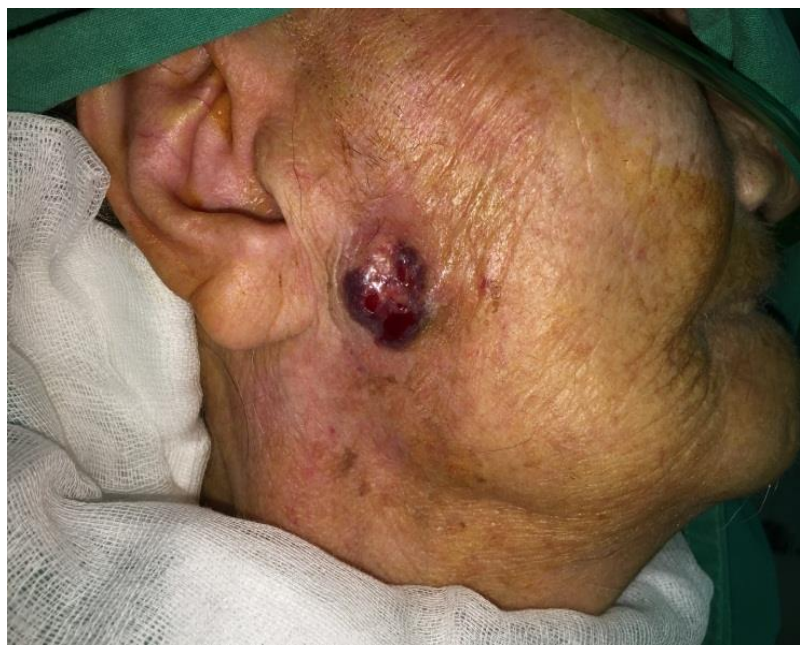

Figure 1. Exulcerated tumor formation in the right parotid region

As a part of the preoperative preparation, exciseonal biopsy of the tumefaction was performed, which indicated the presence of an invasive ductal carcinoma, as well as a CXR (chest x-ray) and AXR (abdominal $x$-ray), which did not indicate the presence of any secon-dary deposits.

Multi-slice CT of the head and neck region was performed as well, indicating the presence of an expansive tumor formation in the neck and lower jaw ramus area, with an extension into the bone and soft-tissue structures of the upper jaw joint (TMJ) and into the infratemporal space (Figure 2). Along with that, the presence of neck lymphadenopathy, levels I, II and III, was established as well.

On the account of clinical findings such as these and histopathological verification of disseminated primary malignant disease, modified radical neck dissection type III was performed (MRND, Type III) in general endotracheal anesthesia (GETA), fol- lowed by hemimandibulectomy with disarticulation of the TMJ (temporomandibular joint), tumor extirpation in the infratemporal fossa, excision of the tumor in the preauriacular region, with an adequate reconstruction of the created soft tissue defect with a cervicofacial flap. The post-operative course was uneventful, and the patient was released from the clinic on the tenth postoperative day.

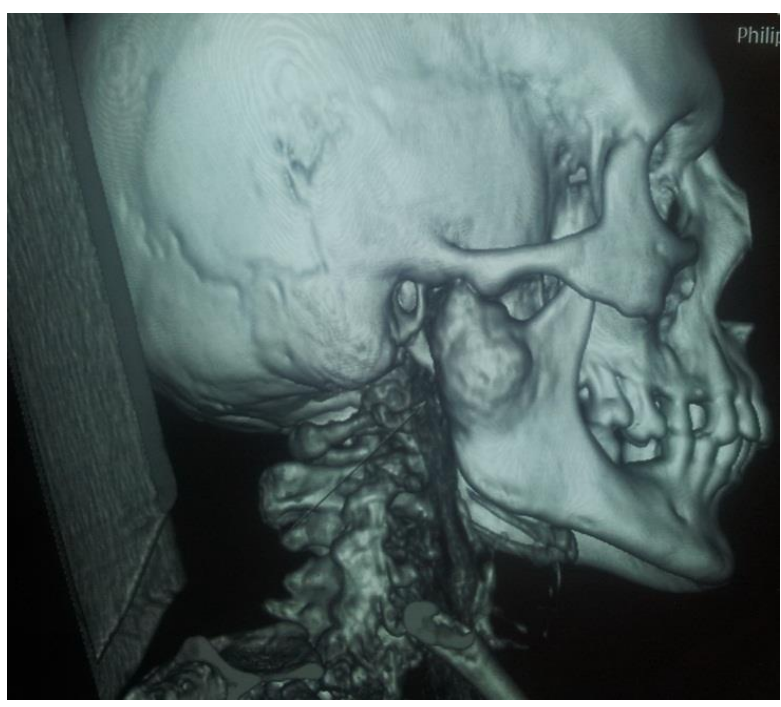

Figure 2. MSCT of the head and neck: an expansive tumor formation in the lower jaw

Histopathological analysis revealed the presence of a moderately to poorly differentiated tumor process in the tissue sample sent for analysis, composed of polygonal cells with prominent nuclei and nucleoli, containing a large number of pathological mitoses. Tumor cells for the most part demonstrated a solid tumor growth pattern, creating focal glandular arrangements (Figure 3). Moreover, vast fields of necrosis were present as well. Immunohistochemical analysis confirmed the presence of a secondary deposit originating from a malignancy in the breast. The observed cells expressed CK7, while the results were negative for $\mathrm{Er}, \mathrm{Pr}$ and HER2. The steroid receptor status matched the initial, primary tumor status.

Lymphonodal findings in the neck indicated the presence of a metastatic process (12/27).

Histopathological verification of an invasive ductal carcinoma with positive lymph nodes in the neck necessitated the approach with chemoradiation therapy. After the completion of oncological treatment, the management continued with regular postdischarge monthly follow-up examinations, during which the absence of tumor recurrence 18 months after the surgery was confirmed. 


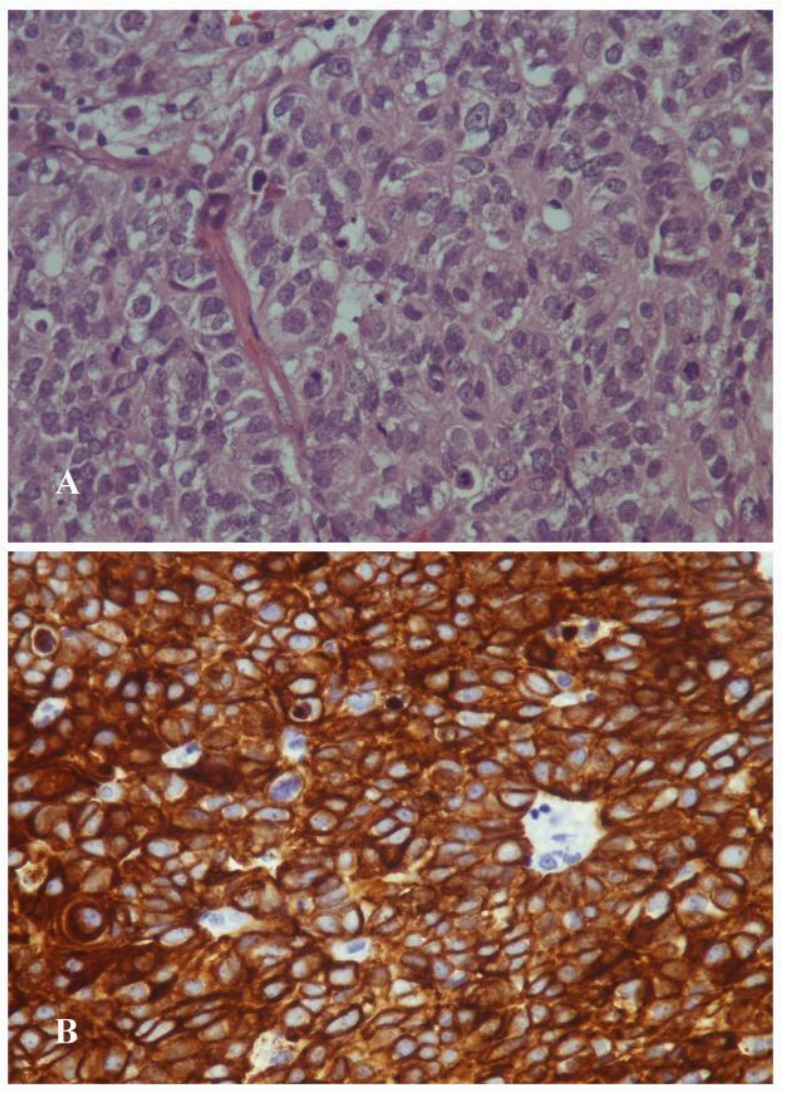

Figure 3. Tumor cells arranged predominantly in solid focal fields, with the formation of glandular structures A-H\&Ex40 B-CK7X40

\section{Discussion}

Breast cancer represents a malignant proliferation of epithelial cells. Breast cancers represent the most frequent tumor type among women (excluding skin tumors). Long-term studies have shown that the risk of developing breast cancer grows with age; however, a decreased incidence of breast tumors from the onset of menopause has been reported. In the life of every woman we can recognize the three stages that have the greatest impact on the development of breast cancer; these are the age at menarche, the age at first pregnancy, and the age at the onset of menopause. According to the data from 2007 , there were 180,510 new breast cancer cases in the USA, with 40,910 reported deaths from breast cancer (6).

Metastatic tumors in the oral cavity are rare, and comprise about $1 \%$ of all oral cavity malignancies (7).

The lower jaw is more frequently affected than the maxilla, and the predilection area for the development of metastases is the region of the lower jaw body and ramus (8).

Out of all metastatic tumors affecting the oral cavity and jaws, about $61 \%$ occur in the mandible, $24 \%$ in maxilla, and $15 \%$ in soft tissues. Primary tumors that metastasize to the mandible area are most frequently those affecting the breast (31\%), lungs (18\%), kidney (15\%), thyroid, prostate and colon (6\%), abdomen and skin (5\%), testicle (3\%), urinary bladder, liver, uterus and ovary (1\%) (9).

The study conducted by Babatunde O. Akinbami, during the 30-year period, involved 1.537 patients with malignant tumors in the oral cavity, 24 of which were metastatic. Among these, 14 were located in the mandible, 4 in maxilla, and only 1 affected both the maxilla and mandible. Out of these 24 cases, 12 were females. In 4 women of these, the primary tumor was localized in the breast and had metastasized to the lower jaw (8).

Examining the 114 cases of metastatic jaw tumors by D'Silva, it was found that the most frequent symptom of these tumors was pain. The remaining signs and symptoms included the presence of a swelling, intraoral tumor mass, tooth loss, loose teeth, regional lymphadenopathy, gingival irritation, ulceration, exophytic growth, bad breath, trismus, lower lip paresthesia (10). Reviewing the bone x-ray findings in such cases, it can be noticed that the occurrence of metastatic tumors may vary from distinctly limited to vaguely limited, which we often describe as a "moth eaten" appearance. In the study by Hirshberg in 2008, which included 673 patients, it was concluded that $5 \%$ of the cases did not have any radiographic changes. It is known that a familial history plays an important role in the development of breast cancer. Around $10 \%$ of breast cancers are directly asso-ciated with embryonic mutations. The Li Fraumani syndrome is characterized by an inherited mutation of the p53 tumor suppressor gene, which produces an increased incidence of breast tumors, osteosarcoma and other malignancies. Inherited mutations of the PTEN gene are also associated with the development of breast tumors. A tumor suppressor gene, BRCA-1, could be held responsible for the activation of a zinc finger protein, after which it functions as a transcription factor. This gene is also involved in the action of "repair genes". A woman who inherits the allele mutation of this gene, regardless of her parent's status, has a $60-80 \%$ greater chance to develop a breast cancer, and 33 $\%$ greater chance to develop an ovarian cancer. In men, this mutation increases the risk for prostate cancer. BRCA-2 also affects the growth of incidence of breast tumors. A p53 mutation is present in about $40 \%$ of patients with breast tumors. An acquired mutation of the PTEN gene occurs in around $10 \%$ of those affected with breast tumors. With some breast tumors, a decreased expression of BRCA-1 gene and an abnormal location of BRCA-1 protein has been recognized. It can be concluded that a weaker BRCA-1 and BRCA-2 tumor suppressor gene expression has a sporadic influence on the occurrence of breast cancer. With around $25 \%$ of the patients, an enhanced dominant oncogene expression has an important role in the development of breast cancer. The product of this gene belongs to the family of epidermal growth factor receptors; it is called erbB2 (HER2), and its hyperexpression has been reported in breast tumors (11).

ErbB2 (HER2) is a "growth signal molecule" which can be found on the surface of normal breast epithelial cells, the values of which may increase to 
an extreme level in $20 \%$ of breast cancers, indicating an autonomous growth and genetic instability, and consequentially, its increased expression indicates a greater chance for tumor recurrence, and hence a poor prognosis (12).

An extreme increase of HER2 values has been found in $20 \%$ of those diagnosed with breast cancer; it thus indicates a shorter survival time and more aggressive clinical course of the disease, compared to the tumors with normal HER2 values (13).

Breast tumors with negative ER/PR receptor status have poorer prognosis than those with positive ER/ PR receptor status, the reason for that being that with positive ER/PR receptors there is a possibility for initia-ting a hormone therapy (14).

The prognosis in patients having condylar metastases is very poor, since out of these $70 \%$ are estimated to already have distant metastases (15). Considering the above data related to clinical presentation and prognostic parameters, we may conclude that the prognosis for the patient described in this paper is rather uncertain.

Another important prognosis factor for breast cancer is the proliferative index or Ki67 index (16). The tumors showing a higher value of this index generally have poorer prognosis. Moreover, the values of Ki67 protein have an impact on the choice of therapy, so that with hormonedependent tumors with high Ki67 values adjuvant chemotherapy is usually advised because of the tumor tendency to recur. It is worth mentioning that in 2000, a molecular classification of breast carcinoma was published, describing these 4 subtypes:

1. Luminal,

2. Her2-expressing,

3. Basal-like,

4. Normal breast look-alike cancer (17).

A reclassification of this division followed soon, by the International Breast Cancer Study Group, which was published in St. Gallen in 2011, and which was related to immunohistochemical expression of hormone receptors of Her2, ER/PR and proliferative index of Ki67, according to which all breast cancers were divided into 4 subtypes as follows:
1. Luminal $A$,
2. Luminal B,
3. Her2-positive,
4. Triple negative/basal-like (Table 1 ).

Table 1. Molecular classification of invasive breast carcinoma st. Gallen, 2011 (18)

\begin{tabular}{|c|c|c|c|c|c|c|}
\hline "Molecular subtype & Surrogate subtype & 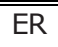 & & 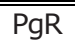 & "HER2 & PI (Ki-67) \\
\hline Luminal A & Luminal A-like & + & or & + & - & $<14 \%$ \\
\hline \multirow[t]{4}{*}{ Luminal B } & Luminal B-like & + & or & + & - & $\geq 14 \%$ \\
\hline & (HER2-negative) & & & & & \\
\hline & Luminal B-like & + & or & + & + & Any \\
\hline & (HER2-positive) & & & & & \\
\hline HER2-overexpression & HER2-positive & - & & - & + & Any \\
\hline Basal-like & Triple negative & - & & - & - & Any \\
\hline
\end{tabular}

ER: estrogen receptor; PgR: Progesterone receptor; HER2: Human epidermal growth factor receptor 2;

PI: Proliferation index; +: Positive; -: Negative

In the case of the patient described in this paper, the values of erbB2 (Her2), PR/ER were as follows:

- Her2-negative;

- ER- negative;

- PR- negative;

- Ki67- positive (26\%).

Taking into account the measured hormone receptor values and according to the reclassification by the International Breast Cancer Study Group in St. Gallen in 2011, the breast cancer described in this patient belonged to the forth group - basal-like cancer type. In the cases of a basal-like cancer type with negative Her2 and ER/PR values, hormonal the- rapy was not indicated, and the patient underwent chemoradiation therapy following the surgical treatment.

\section{Conclusion}

Despite their being relatively rare clinical entities, tumors metastatic to the head and neck region represent a specific type of challenge in the practice of a surgical oncologist. Most of the patients are definitively diagnos-ed in more advanced disease stages, which makes the prognosis of their disease very uncertain. A detailed patient history with complete clinical examination and biopsy with supple- 
mental radiological findings, are vital for making the definitive diagnosis and for a therapy to be successful. Based on the presented findings, it can be concluded that an adequate surgical therapy, with proper immunohistochemistry and determination of the type and subtype of these carcinomas, represents a promising, individualized oncological approach in the treat-ment of affected patients, increasing the percentage of therapeutic success and healing rates.

\section{References}

1. Hirshberg A, Berger R, Allon I, Kaplan I. Metastatic tumors to the jaws and mouth. Head Neck Pathol 2014; 8(4):463-74. [CrossRef] [PubMed]

2. McClure SA, Movahed R, Salama A, Ord RA. Maxillofacial metastases: a retrospective review of one institution's 15-year experience. J Oral Maxillofac Surg 2013; 71(1):178-88. [CrossRef] [PubMed]

3. Owosho AA, Xu B, Kadempour A, Yom SK, Randazzo J, Ghossein RA, et al. Metastatic solid tumors to the jaw and oral soft tissue: A retrospective clinical analysis of 44 patients from a single institution. J Craniomaxillofac Surg 2016; 44(8):1047-53. [CrossRef] [PubMed]

4. Allon I, Pessing A, Kaplan I, Allon DM, Hirshberg A. Metastatic tumors to the gingiva and the presence of teeth as a contributing factor: a literature analysis. ] Periodontol 2014; 85(1): 132-9. [CrossRef] [PubMed]

5. Thiele OC, Freier K, Bacon C, Flechtenmacher C, Scherfler S, Seeberger R. Craniofacial metastases: a 20-year survey. J Craniomaxillofac Surg 2011; 39 (2):135-7. [CrossRef] [PubMed]

6. Wiener C, Fauci AS, Braunwald E, Kasper DL, Hauser $\mathrm{SL}$, Longo DL, Jameson JL, Loscalzo J. Harrison's principles of internal medicine. Self-Assessment \& Board Review. $17^{\text {th }}$ ed. New York: McGraw-Hill Companies; 2008.

7. Dib LL, Soares AL, Sandoval RL, Nannmark U. Breast metastasis around dental implants: a case report. Clin Implant Dent Relat Res 2007; 9(2):112-5.

[CrossRef] [PubMed]

8. Akinbami BO. Metastatic carcinoma od jaws: a review of literature. Niger J Med 2009; 18(2):139-42.

[CrossRef] [PubMed]

9. Rocha WC, Curado MP, Vencio EF, Caixeta WB. Endometrial carcinoma metastatic to the mandible: a case report. J Oral Maxillofac Surg 2000; 58(8):914-6. [CrossRef] [PubMed]

10. Menezes AV, Lima MP, Mendonca JE, Haiter-Neto F, Kurita LM. Breast adenocarcinoma mimicking temporomandibular disorders: a case report. J Contemp Dent Pract 2008; 9(5):100-6. [CrossRef] [PubMed]
11. Hirshberg A, Shnaiderman-Shapiro A, Kaplan I, Berger R. Metastatic tumours to the oral cavity- pathogenesis and analysis of 673 cases. Oral Oncol 2008; 44(8): 743-52. [CrossRef] [PubMed]

12. Abeloff MD, Weber BL, Wolff AC, McCormick B, Zaks TZ, Sacchini V. Cancer of the breast. In: Abeloff MD, Armitage JO, Niederhuter JE, Kastan MB, McKena WG, editors. Abeloff's Clinical Oncology. 4th ed. London: Churchill Livingstone; 2008.

13. Wolff AC, Hammond ME, Schwartz JN, Hagerty KL, Allred DC, Cote RJ, et al. American Society of Clinical Oncology/College of American Pathologists guideline recommendations for human epidermal growth factor receptor 2 testing in breast cancer. Arch Pathol Lab Med 2007; 131(1):18-43. [PubMed]

14. Fisher B, Redmond C, Fisher ER, Caplan R. Relative worth of estrogen or progesterone receptor and pathologic characteristics of differentiation as indicators of prognosis in node negative breast cancer patients: findings from National Surgical Adjuvant Breast and Bowel Project Protocol B-06. J Clin Oncol 1988; 6(7):1076-87. [CrossRef] [PubMed]

15. Kaufmann MG, Perren A, Gratz KW, Eyrich GKH. Condylar metastasis. Review of the literature and report of a case. Mund Kiefer Gesichtschir 2005; 9(5): 336-40. [CrossRef] [PubMed]

16. Horimoto Y, Arakawa A, Tanabe M, Kuroda K, Matsuoka J, Igari $F$, et al. Menstrual cycle could affect $\mathrm{Ki}-67$ expression in estrogen receptor-positive breast cancer patients. J Clin Pathol 2015; 68(10):825-9. [CrossRef] [PubMed]

17. Perou CM, Sorlie T, Eisen MB, Van de Rijn M, Jeffrey SS, Rees CA, et al. Molecular portraits of human breast tumours. Nature 2000; 406(6797):747-52. [CrossRef] [PubMed]

18. Goldhirsch A, Wood WC, Coates AS, Gelber RD, Thürlimann B, Senn HJ. Strategies for subtypes dealing with the diversity of breast cancer: highlights of the St. Gallen international expert consensus on the primary therapy of early breast cancer 2011. Ann Oncol 2011; 22(8):1736-47. [CrossRef] [PubMed] 


\title{
METASTAZA INVAZIVNOG DUKTALNOG KARCINOMA DOJKE U PREDELU TEMPOROMANDIBULARNOG ZGLOBA DVE GODINE NAKON INICIJALNOG TRETMANA: PRIKAZ SLUČAJA
}

\author{
Predrag Radović1,2, Milovan Papović1, Miloš Trajković1 ${ }^{1}$ Nikola Živković2,3, Andrija Ćosić1,2
}

\author{
${ }^{1}$ Klinika za stomatologiju, Odeljenje za maksilofacijalnu hirurgiju, Niš, Srbija \\ 2Univerzitet u Nišu, Medicinski fakultet Niš, Srbija \\ ${ }^{3}$ Institut za patologiju, Niš, Srbija \\ Kontakt: Milovan Papović \\ Bulevar dr Zoran Djindjić 48, 18000 Niš, Serbia \\ E-mail: milovanpapovic@gmail.com
}

Metastaze tumora u predelu usne duplje i vilice predstavljaju redak patološki entitet. Ovakvi tipovi tumora predstavljaju težak izazov za onkološke hirurge zbog otežane dijagnostike, nespecifične simptomatologije i netipičnog radiografskog nalaza. Simptomi koji se javljaju kod metastatskih tumora temporomandibularnog zgloba i ramusa donje vilice najčešće su nespecifični i manifestuju se u vidu bolnih senzacija, otoka, otežanog otvaranja usta, što kliničara često odvodi na oboljenja temporomandibularnog zgloba kao što su artritis, subluksacija zgloba, degenerativne promene i infekcije.

$U$ našem slučaju prikazana je pacijentkinja stara 62 godine sa postojanjem metastatskog tumora u predelu temporomandibularnog zgloba i donje vilice sa veoma neizvesnom prognozom. U daljem tekstu diskutovaće se o izobru hirurške i onkološke terapije na osnovu radiografskih nalaza i histopatološkog tipa karcinoma

Acta Medica Medianae 2020;59(1):90-95.

Ključne reči: metastaza karcinoma dojke, temporomandibularni zglob, histopatološki tip i podtip, hirurški tretman 